\title{
MINERALOGY OF CHROMITITE, BULQIZA ULTRAMAFIC MASSIF, ALBANIAN OPHIOLITIC COMPLEX
}

\author{
Çina A. \\ Institute of Geosciences, Polytechnic University of Tirana. Str. Don Bosco, Nr. 60. \\ al_cina@yahoo.com
}

\begin{abstract}
Ultramafic massif of Bulqiza belongs to Eastern Jurassic Albanian ophiolite belt of IAT-BSV-type. This massif is the most important chromite-bearing ore. The mantle ultramafics have extremely refractory nature. This is due to the high partial fusion of upper mantle which is depleted in $\mathrm{CaO}$ and $\mathrm{Al}_{2} \mathrm{O}_{3}$. The chromitite is situated to different parts of ultramafic pile, from bottom Cpx-harzburgites up to massive dunites and cumulate ultramafic but the mainly chromite potential belongs to mantle harzburgite -dunite level and to transition dunites partly. The chromite is chiefly of Cr-rich metallurgical type. The atomic ratios of chromite, Fo of olivine and some physical properties of them vary according to the chromitite setting and reflects the evolution of Ol-Sp equilibrium process depended of the chromite concentration, from baren dunitic lenses towards dunite envelops of the ore bodies and the interstitial and inclusions of olivine within chromite grains. Two particular chromite deposits are the Bulqiza-Batra tabular folded ore body and Shkalla, pencil-like ore body.
\end{abstract}

Key words: Chromitite mineralogy, ultramafic, massif Bulqiza Albania.

\section{Introduction}

Widespread ophiolitic rocks in Albania occur along two ophiolitic belts, the Western and the Eastern ones characterized by individual petrological, geochemical and metallogenic features .The Western belt comprises ophiolitic rocks of Jurassic age and MOR-type affinity and includes high - Ti basaltic rocks. On the contrary, the ophiolitic rocks of Eastern belt show IAT type geochemical character and comprise of low-Ti basalts. This belt suggested that it is formed over a subduction zone (SSZ) (Alliu et al., 1994; Shallo et al., 1995; Kodra et al., 1995). This ophiolitic belt is composed by some massifs, with them, the Bulqiza massif is most important for its high chromite- bearing. Many chromite occurences and some big and very big deposits are situated in this massif related chiefly to harzburgite -dunitic mantle part and partly with super MOHO-dunites. The ore body are folded tabular, podiform, banded - layered and pencil - like even. The principal rock constituent are mantle harzurgites and super MOHO -dunites, whereas the Pl-dunites, lherzolites, wehrlites, pyroxenites and gabbroic rocks, are less abbundant. The Bulqiza massif, similarly to other Eastern ophiolitic complexes such the Vurinous and Troodos. (Çina et al., 1986; Econoumu et al., 1986; Panayiotou et al., 1986), has been affected by intensive partial melting of the upper mantle as it is implying by depletion in $\mathrm{CaO}$ and $\mathrm{Al}_{2} \mathrm{O}_{3}$ and enrichment in $\mathrm{MgO}$ and $\mathrm{Cr}_{2} \mathrm{O}_{3}$ of the mantle rocks. The chromite is of $\mathrm{Cr}$-rich, metallurgical type, with a few exceptions, for some occurances composed by Al- rich chromite - type .It is remarkable that olivine as dunite and chromitite - component is two much forsteritic type. The morphology and textures of ore body as well as the chemical composi- 
tion and some physical properties of chromite are subordinated related to their geological setting, from Cpx- harzburgite of deeper part to upwords super MOHO-dunites and ultramafite - mafite sequences. All the same ,the composition of olivine is variable related to chromite concentration, as reflection of equilibrium process between ol- sp. The aim of this review is to make known the mineralogy of chromitite of one of the most distinguished chromitite-bearing ultramafic massif of Bulqiza, and wider for the Eastern ophiolitic complexes in general.

\subsection{Analyses' methods and conditions.}

The analyses of chromite and olivine are brought out by electronic microprobe CAMEBAX under the conditions accelerating voltage $15 \mathrm{kV}$ and a current of $10 \mathrm{nA}$, time of caption $10 \mathrm{sec}$. The correction programme ZAF by Honoc and Tong (1978). The analyses have been conducted in MGA-BRGM, France by Ch. Gilles and D. Ohnenstetter. The parameter of the elementary cell of chromite have been extracted from the Ro-analyse with $4 x$ time camera of Guinier and Wolff, anticathode $\mathrm{Cu}-\mathrm{Ka} 1$, $36 \mathrm{kV}, 20 \mathrm{~mA}$ with the assistance of F. Pillard at MGA-Mineralogy Geochemistry Analyses, France.

\section{Geology and chromitite-bearing of the massif.}

The Bulqiza ultramafic massif is situated at Eastern ophiolitic belt. It covers a surface of $350 \mathrm{~km}^{2}$, with a thickness about $5-6 \mathrm{~km}$. It is surrounded by different sediments, from Triassic, Triassic Jurassic limestones, and partly is covered by Cretaceous limestones and Neogenic molassic sediments. This massif consists mainly of mantle harzburgites, Eastern and central part, by super MOHO dunites ,South - Western and Western parts and by ultramafic - mafic intrusive rocks at Western side (Fig.1). This massif is remarkable for its high chromite- bearing mineralization. About 100 occurances and 15 deposits occur. Among them, some are big and very big as Bulqiza - Batra, Shkalla, Thekna, Ternova, Lugu Gjat, and Krasta deposits. The most important chromite mineralization is situated at central part of massif related to harzburgite - dunites, and partly at South South - Western part related to super - MOHO dunites. Only from Bulqiza - Batra deposits are extracted about 20 mega ton high grande chromite ore. The ore bodies have tabular concordant and semi concordant folded shapes, podiform and banded-layered, even pencil -like morphology. The exceptional is Bulqiza deposit represented by tabular folded ore bodies, $5000 \mathrm{~m}$ in strike and 0,5 up to 5-10 m thick. The ore body came out at the height of $1570 \mathrm{~m}$ over the sea level and goes down to $300 \mathrm{~m}$ under the sea level. The other particular deposit is Shkalla, pencil - like ore bodies . These have oval - shaped surface section from 5 to $25 \mathrm{~m}^{2}$ and go up to $1500 \mathrm{~m}$ downwards. The chromite is Cr-rich metallurgical high grande type. It is situated at different part of ultramafic pile, from that related to deep mantle cpx - harzburgites, towards upper harzburgite - dunite and dunite - harzburgite parts, up to super -MOHO dunites, even to ultramafite - mafite and troctolite sequences. The most chromite -bearing potential is situated at 300 up $1200 \mathrm{~m}$ interval below super-MOHO dunites and only low - grande chromite ores are related at middle - deep dunitic sequence (Fig.2). The chromite ore grade concerning its geological setting decreases from mantle harzburgite - dunitic level of high to highest grande from $37 \%$ to $45 \% \mathrm{Cr}_{2} \mathrm{O}_{3}$ even $53 \% \mathrm{Cr}_{2} \mathrm{O} 3$ for pencil -like ore body, upwards for dunite - harzburgite part (middle grade, from $30 \%$ to $35 \% \mathrm{Cr}_{2} \mathrm{O}_{3}$ ) and particularly for super - MOHO dunites (lower grade, from $18 \%$ to $25 \% \mathrm{Cr}_{2} \mathrm{O}_{3}$ ).

\subsection{Petrography}

The most common mineral components of chromitites are chromite and olivine, as well as serpentine. In small quantities occur also the other silicate minerals clinopyroxen, orthopyroxen, amfi- 


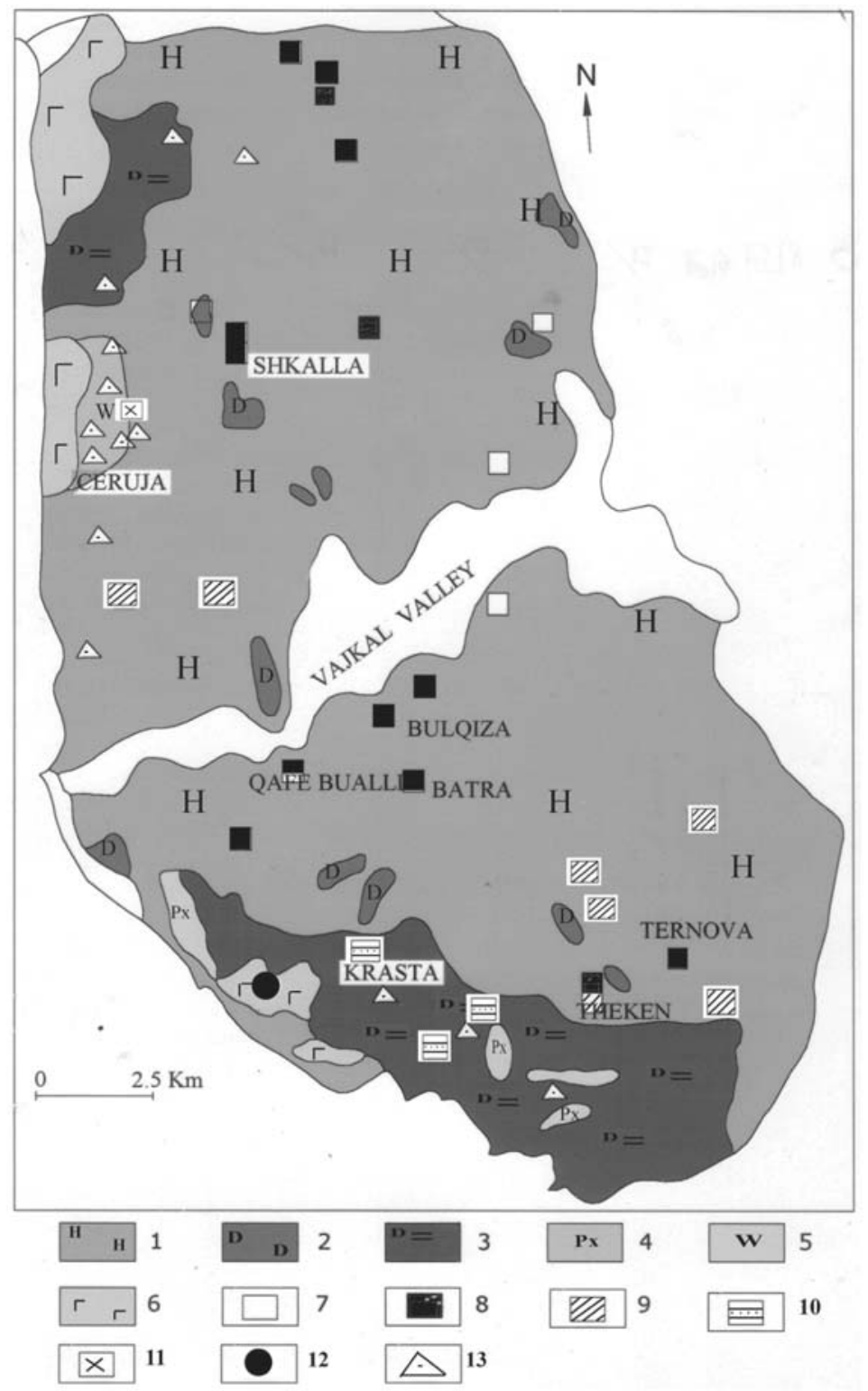

Fig. 1: Geological map of Bulqiza ultramafic massif and related mineralization.

1: Mantle harzburgites; 2: Mantle dunites , 3: Super - MOHO dunites, 4: Pyroxenites, 5:Wehrlites, pl - lherzolites ,pyroxenites; gabbros; 6: Gabbro- troctolites.

Chromite mineralization related to:

7: Deep mantle, cpx - harzburgites, $\mathrm{Al}$ - rich chromite type. 8: Middle mantle, harzburgite - dunite level, $\mathrm{Cr}$ rich chromite type; 9: Upper mantle, dunite - hazburgite level, Cr- rich chromite type; 10: Super - MOHO dunitic transition zone, Cr- rich chromite type; 11: Ultramafite -mafite, cumulate sequences and intrusive rocks, $\mathrm{Al}$-rich type chromite; 12: Troctolite sequence, $\mathrm{Al}$ - rich chromite; 13: $\mathrm{Ni}$ and $\mathrm{Ni}$ - $\mathrm{Cu}$ sulphide mineralization associated by PGM. 


\begin{tabular}{|c|c|c|c|c|c|}
\hline & LITHOLOGY & $\begin{array}{l}\text { CHROMITE TYPES, } \\
\text { GRADE ORE }\end{array}$ & $\begin{array}{l}\mathrm{Cr} \#(\mathrm{~mol} . \\
100 \times \mathrm{Cr} / \\
(\mathrm{Cr}+\mathrm{Al})\end{array}$ & $\begin{array}{l}\mathrm{Mg} \#(\mathrm{~mol} \\
100 x \mathrm{Mg} / \\
(\mathrm{Mg}+\mathrm{Fe})\end{array}$ & $\begin{array}{l}\text { Elemen- } \\
\text { tary cell } \\
a_{0} \AA\end{array}$ \\
\hline \multirow{2}{*}{ 这兗 } & TROCTOLITE & $\begin{array}{l}\text { Al- RICH } \\
\text { REFRACTARY TYPE }\end{array}$ & 42.7 & 79.8 & 8.198 \\
\hline & WEHRLITE & $\begin{array}{l}\text { Al- RICH } \\
\text { REFRACTARY TYPE } \\
\text { MED - GRADE ORE }\end{array}$ & 52.9 & 68.3 & 8.239 \\
\hline 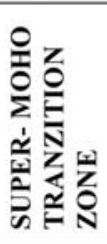 & $\begin{array}{l}\text { MASSIVE } \\
\text { DUNITES }\end{array}$ & $\begin{array}{l}\text { Cr-RICH } \\
\text { METALLURGIRCAL } \\
\text { TYPE, } \\
\text { LOW-GRADE ORE }\end{array}$ & $\begin{array}{l}81.6- \\
83.5\end{array}$ & $70-78.5$ & $\begin{array}{l}8.309- \\
8.326\end{array}$ \\
\hline \multirow{3}{*}{ 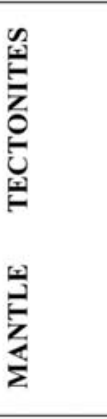 } & $\begin{array}{l}\text { DUNITE- } \\
\text { HARZBURGITE }\end{array}$ & $\begin{array}{l}\text { Cr-RICH } \\
\text { METALLURGIRCAL } \\
\text { TYPE, } \\
\text { LOW-MED.-GRADE } \\
\text { ORE }\end{array}$ & $80.9-82.7$ & $\begin{array}{l}64.3- \\
70.5\end{array}$ & 8.306 \\
\hline & $\begin{array}{l}\text { HARZBURGITE } \\
\text { DUNITE }\end{array}$ & $\begin{array}{l}\text { Cr-RICH } \\
\text { METALLURGIRCAL } \\
\text { TYPE, } \\
\text { HIGH- GRADE ORE }\end{array}$ & $77.3-81.9$ & $68.8-75$ & $\begin{array}{l}8.285- \\
8.303\end{array}$ \\
\hline & $\begin{array}{l}\text { Cpx - } \\
\text { HARZBURGITE }\end{array}$ & $\begin{array}{l}\text { Al- RICH } \\
\text { REFRACTARY TYPE } \\
\text { MED - GRADE ORE }\end{array}$ & 59.5 & 78.7 & 8.250 \\
\hline
\end{tabular}

Fig. 2: Geological setting, types, grade ores and some significant chemical ratios of chromitites. Eastern opholite belt, ulramafite massif of bulqiza, Albania.

boles, $\mathrm{Cr}$ - diopside, $\mathrm{Cr}$-garnet, $\mathrm{Cr}$-chlorite, BMS and PGM. The minute grains of these minerals are included within host chromite grains and as interstitial forming between them also. It is interesting to point out the presence of uvarovite and kemmererite related to massive chromitite of vein - like ore body. The sulphide and arsenide of BME as pentlandite, millerite heazlewoodite, nickeline, maucherite, pyrrhotite, cubanite as well as of PGE mainly Ru, Os , Ir alloys and their sulphides, are related to super - $\mathrm{MOHO}$ dunites and upper mantle chromitite. The textural features of chromitites of tabular, podiform and vein - like ore bodies are varied, massive, dense dissemination and nodular. For banded - layered ore bodies disseminated and banded texture are characteristic. Some textural features of them testify on magmatic plastic deformation processes, and posmagmatic budinage (Figs 3: a, b, c and d). The chromite grains display euhedral and subhedral shape with 1 to $2 \mathrm{~mm}$ up to $5 \mathrm{~mm}$ dimensions (Figs $4: \mathrm{a}, \mathrm{b}$ and c). For the disseminated chromitite related to dunites, euhedral shape and less $1 \mathrm{~mm}$ size are more characteristic. The chromite grains contain many different inclusions, opx, cpx, ol, BMS and PMG (Figs 4: $\mathrm{d}$ and e). The partly metamorphosed chromite grains and transformed into $\mathrm{Fe}$ - chromite up to magnetite and its veinlets are observed. (Fig 4: f).

\subsection{Chemical composition of chromite in the various chromitite types}

The $\mathrm{Cr} \#$ in spinel can be regarded as a sensitive chemical parameter for the degree of depletion as long as it lies above 15 (Dick and Bullen 1984). The main chromites of Bulqiza massif show high$\mathrm{Cr}$ character (Cr\# vary from 77 to 83.5). The most frequent $\mathrm{Mg}$ \# ratios is from 64.3 to 78 . Only a few of them are of Al-rich type, with $\mathrm{Cr} \#$ from 53 to 59. The associated olivine is of the high 

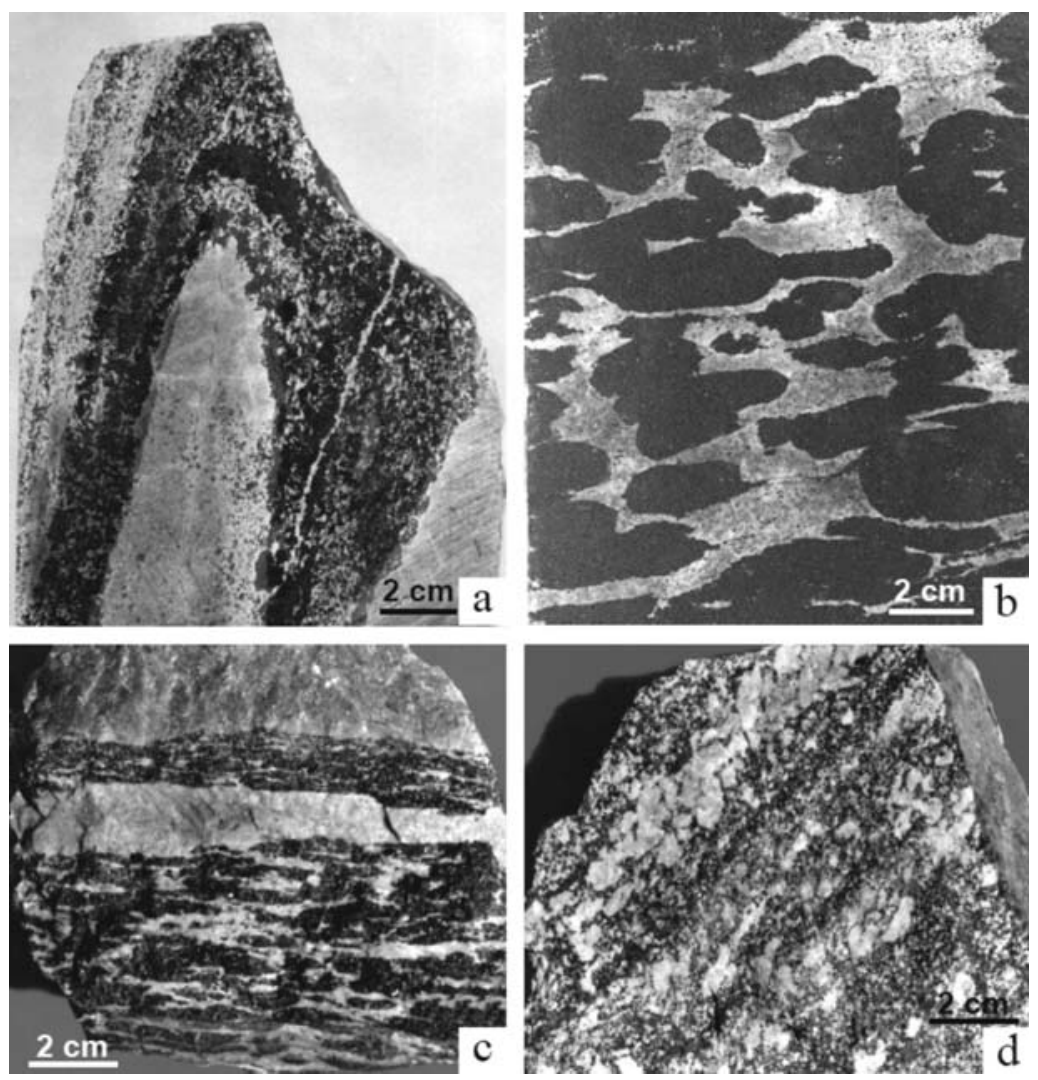

Fig. 3: a: The plastic sindeformed chromitite. The foliation plan of isoclin fold is parallel to axial plan of folding; b: Nodular chromitite, intensively deformed. The nodules are extended and crushed by strong attraction; Fig. c: The buddined chromitite transformed into banded - like shope. The pull-a- part lineation is expressed clearly; d: The chromitite intensively deformed ,transformed into lensoide - brekccious up to antinodular - shape.

forsteritic type, Fo from 90 to 96 . In accordance with chromite composition the physical properties are not so variable. So, among them, the elementary cell parameter $\mathrm{a}_{0}$, in average is from $8.285 \AA$ to $8.326 \AA$, regardless some exceptions for the chromites related to deep Cpx-harzburgites and for these relate to ultramafic cumulates $\left(\mathrm{a}_{0}=8.25\right.$ and $8.239 \AA$ ) (Fig 2.). Nevertheless, a clear tendency is evident regarding the correlation between chemical composition and its geological setting, from bottem Cpx -harzburgites to top super -MOHO dunites and ultramafic - mafic part. So, the Cr\# ratios and some physical properties encrease, wereas the $\mathrm{Mg} \#$ decrease from bottem upwards to top ultramafic pile. By the contrast, the chromite related to ultramafic- mafic sequence have lower $\mathrm{Cr} \#$ and $\mathrm{a}_{0}$, and high Mg\# especially this related to troctolites (Fig. 2). The chemical composition of chromite for some particular deposits are reported in Table 1. Those compositions are different from less depleted Western ophiolitic belt of Al- rich nature mainly (Fig. 5). The chromite of Bulqiza massif is similar with Vourinos massif in Greece. The chromite of its Xerolivado and Skoumtsa deposits has $\mathrm{Cr}$ from 0.80 to 0.83 and $\mathrm{Mg} \#$ from 0.65 to 0.68 . (Economou et al., 1986). But the similarity to chromite from Troodos (Kokkinoratsos, Kannures and Hadjipavlou) is less evident, because its chemical indicators are lower, $\mathrm{Cr} \#$ from 0.72 to 0.76 and $\mathrm{Mg} \#$ from 0.61 to 0.63. (Panayiotou et al., 1986; Dick and Bullen, 1984; Dietrich et al., 1987; Migiros et al., 1988; Konstatopoulou et al., 
Table 1. Chromite deposits: Deep mantle: 1.Takimi Pare, Harzburgit-dunite:2-3 Bulqiza, 4-Batra, 5 Shkalla, 6-Qafe Buall Dunite-harzburgite: 7- Lugu Gjate; 8-Thekna Super MOHO dunite:9Krasta; Ultramafic -mafic cumulates: 10-Crruja;Troctolite :11- Stavec ; Pensil -like chromite Cr-diopsite :12-Maja Hudres. $\mathrm{Cr} \#=100 \mathrm{x} \mathrm{Cr} /(\mathrm{Cr}+\mathrm{Al})$ atom.ratio $\mathrm{Mg} \#=100 \mathrm{x} \mathrm{Mg} /\left(\mathrm{Mg}+\mathrm{Fe}^{2}+\right)$ atom ratio.

\begin{tabular}{|c|c|c|c|c|c|c|c|c|c|c|c|c|}
\hline \multicolumn{13}{|c|}{ Table 1: Chemical composition of chromite ,Bulqiza ultramafite massif, Albania } \\
\hline & 1 & 2 & 3 & 4 & 5 & 6 & 7 & 8 & 9 & 10 & 11 & 12 \\
\hline $\mathrm{SiO}_{2}$ & 0.09 & 0.07 & 0.07 & 0.03 & 0.06 & 0.16 & 0.01 & 0.09 & 0 & 0.06 & 0.2 & 0.11 \\
\hline $\mathrm{THO}_{2}$ & 0 & 0 & 0.07 & 0.1 & 0.07 & 0.18 & 0.08 & 0.16 & 0.06 & 0.26 & 0.16 & 0.05 \\
\hline $\mathrm{Al}_{2} \mathrm{O}_{3}$ & 21.3 & 9.89 & \begin{tabular}{|l|}
10.38 \\
\end{tabular} & 11.49 & 8.8 & 8.6 & 9.51 & 8.73 & 8.98 & 22.8 & 31.73 & 15.22 \\
\hline $\mathrm{Cr}_{2} \mathrm{O}_{3}$ & 46.72 & 59.78 & 58.5 & 58.32 & 59.3 & 61.4 & 59.99 & 59.4 & 59.56 & 42.57 & 35.32 & 53.12 \\
\hline $\mathrm{FeO}$ & 8.07 & 11.13 & 7.5 & 9.45 & 7.51 & 13.39 & 10.51 & 14.55 & 7.63 & 12.67 & 8.07 & 10.46 \\
\hline $\mathrm{Fe}_{2} \mathrm{O}_{3}$ & 5.18 & 3.84 & 5.71 & 4.21 & 6.43 & 1.14 & 3.66 & 4.7 & 6.45 & 4.15 & 5.05 & 4.63 \\
\hline $\mathrm{MnO}$ & 0.31 & 0.39 & 0.37 & 0.27 & 0.32 & 0.19 & 0.34 & 0.27 & 0.43 & 0.17 & 0.34 & 0.36 \\
\hline $\mathrm{MgO}$ & 17.42 & 14.27 & 16.72 & 15.71 & 16.5 & 14.11 & 14.58 & 11.5 & 16.51 & 15.58 & 18.63 & 15.22 \\
\hline $\mathrm{NiO}$ & 0.1 & 0 & 0.09 & 0.11 & 0.36 & 0.09 & 0.05 & 0.08 & 0 & 0.17 & 0.12 & 0.05 \\
\hline $\mathrm{CaO}$ & 0 & 0 & 0 & 0.01 & 0 & 0.01 & 0 & 0.01 & 0 & 0.01 & 0.01 & 0 \\
\hline $\mathrm{V}_{2} \mathrm{O}_{3}$ & 0.17 & 0.12 & 0.15 & 0.18 & 0 & 0.2 & 0.03 & 0.09 & 0.03 & 0.1 & 0.35 & 0.12 \\
\hline $\mathrm{CoO}$ & 0.02 & 0.05 & 0.07 & 0.04 & 0 & 0.02 & 0 & 0.03 & 0 & 0.02 & 0.1 & 0 \\
\hline Total & 31.27 & 29.8 & 30.61 & 29.98 & 31.12 & 29.15 & 29.17 & 31.23 & 31.05 & 32.87 & 32.67 & 30.84 \\
\hline $\mathrm{Si}$ & 0.021 & 0.017 & 0.018 & 0.006 & 0.015 & 0.036 & 0.003 & 0.02 & 0 & & 0.045 & 0.014 \\
\hline$T$ & 0 & 0 & 0.013 & 0.018 & 0.012 & 0.035 & 0.015 & 0.032 & 0.011 & 0.048 & 0.028 & 0.009 \\
\hline Al & 6.069 & 3.01 & 3.1 & 3.43 & 2.66 & 2.655 & 2.914 & 2.717 & 2.705 & 6.595 & 8.563 & 4.522 \\
\hline $\mathrm{Cr}$ & 8.931 & 12.2 & 11.721 & 11.68 & 12.021 & 12.714 & 12.328 & 12.027 & 12.027 & 8.261 & 6.356 & 10.586 \\
\hline $\mathrm{Fe}^{2 *}$ & 1.632 & 2.402 & 1.59 & 2.003 & 1.61 & 2.931 & 2.285 & 3.213 & 1.631 & 26 & 1.546 & 2.205 \\
\hline $\mathrm{Fe}^{3+}$ & 0.943 & 0.746 & 1.089 & 0.802 & 1.241 & 0.245 & 0.715 & 0.934 & 1.239 & 0.768 & 0.87 & 4.63 \\
\hline $\mathrm{Mn}$ & 0.063 & 0.084 & 0.079 & 0.059 & 0.07 & 0.042 & 0.075 & 0.06 & 0.093 & 0.035 & 0.066 & 0.077 \\
\hline $\mathrm{Mg}$ & 6.276 & 5.429 & 6.313 & 5.931 & 6.306 & 5.44 & 5.64 & 4.491 & 6.284 & 5.675 & 6.358 & 5.678 \\
\hline $\mathrm{Ni}$ & 0.02 & 0 & 0.017 & 0.021 & 0.073 & 0.02 & 0.01 & 0.017 & 0 & 0.034 & 0.022 & 0.05 \\
\hline $\mathrm{Ca}$ & & & & 0.003 & & & & & & 0.003 & 0 & \\
\hline $\mathrm{V}$ & 0.032 & 0.026 & 0.031 & 0.036 & 0 & 0.035 & 0.005 & 0.016 & 0.007 & 0.035 & 0.065 & 0.031 \\
\hline Co & 0.003 & 0.01 & 0.023 & 0.008 & 0 & 0 & 0 & 0 & 0 & 0 & 0.019 & 0 \\
\hline Total & 8.969 & 8.697 & 9.142 & 8.863 & 9.3 & 8.713 & 8.73 & 8.731 & 9.254 & 9.15 & 8.946 & 12.671 \\
\hline C\# & 0.595 & 0.802 & 0.791 & 0.773 & 0.819 & 0.827 & 0.809 & 0.82 & 0.816 & 0.529 & 0.427 & 0.701 \\
\hline Mg\# & 0.787 & 0.688 & 0.791 & 0.742 & 0.79 & 0.643 & 0.705 & 0.578 & 0.785 & 0.683 & 0.798 & 0.708 \\
\hline
\end{tabular}

1990; Georgiou et al., 1990; Gartzos et al., 1990). As is reported by Panayiotou et al. (1986), the variabitity of chromite composition is also evident concerning their geological setting in main dunites, harzburgite - dunite contact, transition zone and deep harzburgites.

In the Cr\# vs. Mg\# diagram (Fig. 5) the chromites of Bulqiza massif are compared to the chromites from the other Eastern ophiolitic complexes such as Vourinos and Troodos campareble to the spinels in Tertiary boninites from Western Pacific and Cape Vogel (Papua) and fild for spinels in island are arc-thoeliites (IAT) (Dietrich et al., 1987). 

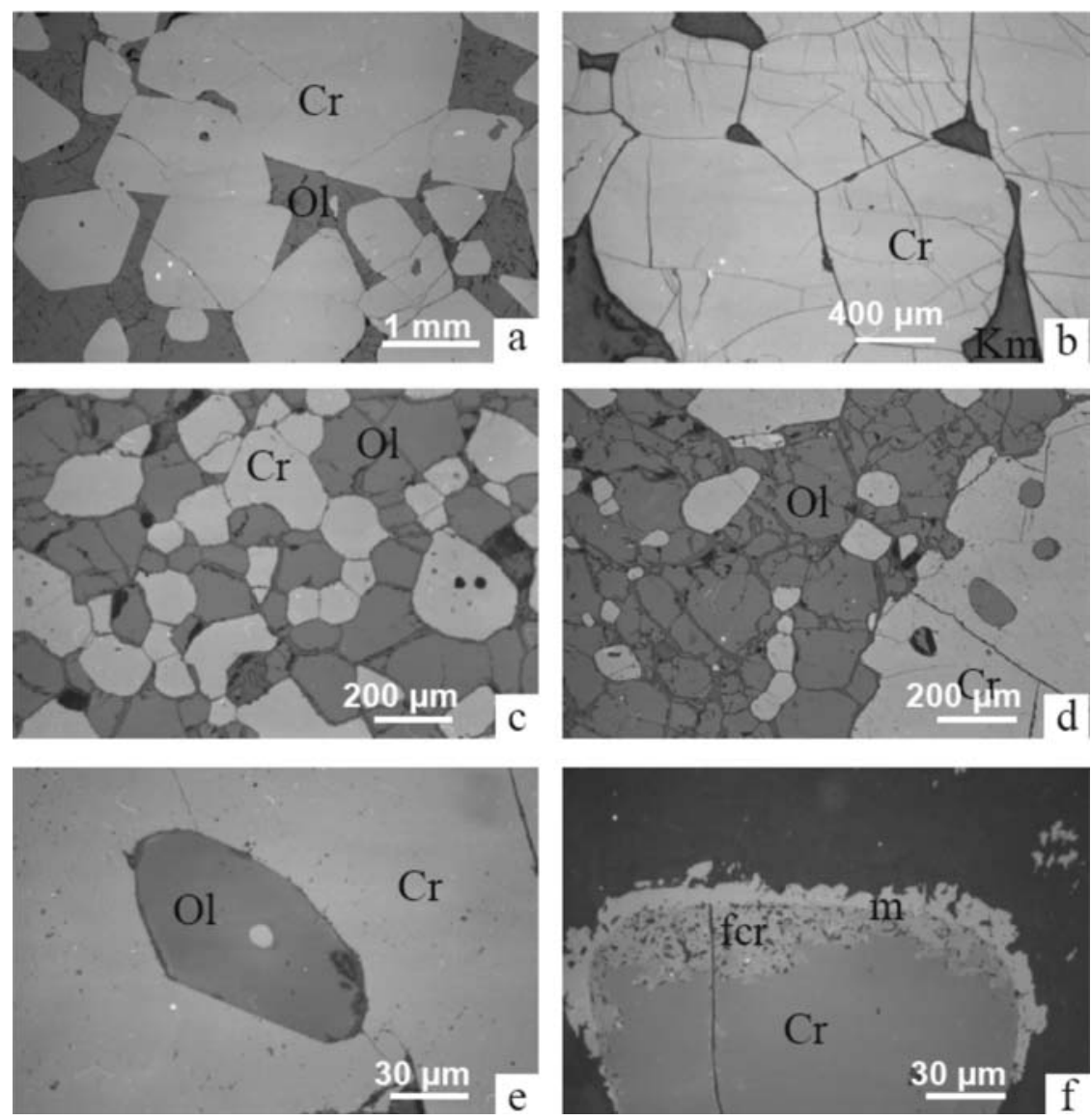

Fig. 4-a: Perfect euhedral chromite crystals $(\mathrm{Cr})$ within olivine $(\mathrm{Ol})$ groundmass; b: Massive chromitite built up by compressed euhedral crystals $(\mathrm{Cr})$. Interstites filled by kemmererite; c: Different euhedral and anhedral chromite grains $(\mathrm{Cr})$ towards olivine ones $(\mathrm{Ol})$; d: The different relation between chromite and olivine: its inclusions $(\mathrm{Ol})$ within chromite $(\mathrm{Cr})$ grains and the contrary; e: The lense shaped olivine inclusions $(\mathrm{Ol})$ within chromite $(\mathrm{Cr})$ grains and the contrary, minute spheric chromite inclusion within bigger olivine inclusion $\mathrm{f}$ : The partly metamorphosed chromite grain $(\mathrm{Cr})$ in to $\mathrm{Fe}$ - chromite ( $\mathrm{fCr}$ ) and surrounded by magnetite rim $(\mathrm{m})$.

A great part of the chromites of Bulqiza massif, such as those related to harzburgite- dunitic, duniteharzburgitic and super $\mathrm{MOHO}$ dunites are characterized by high $\mathrm{Cr} \#$ ratios similarly to those of Troodos, chromites from the main dunite and from southern Vourinos massif. All these chromites are analogues to boninites and IAT environment.

On the contrary, some of the chromites from Bulqiza related to deep Cpx- harzburgites and especially, these related to ultramafic cumulate have low up to very low Cr\# ratios similarly to the others from the contact between the harzburgite and the transition zone of Troodos as well as those from Kissavos and Rodiani are characterized by low $\mathrm{Cr} \#$ ratios.

Regarding to the $\mathrm{Mg} \#$ ratios, the difference between these complexes is less evident. This parameter varies between narrow limits, 62 up to 78 in average. 


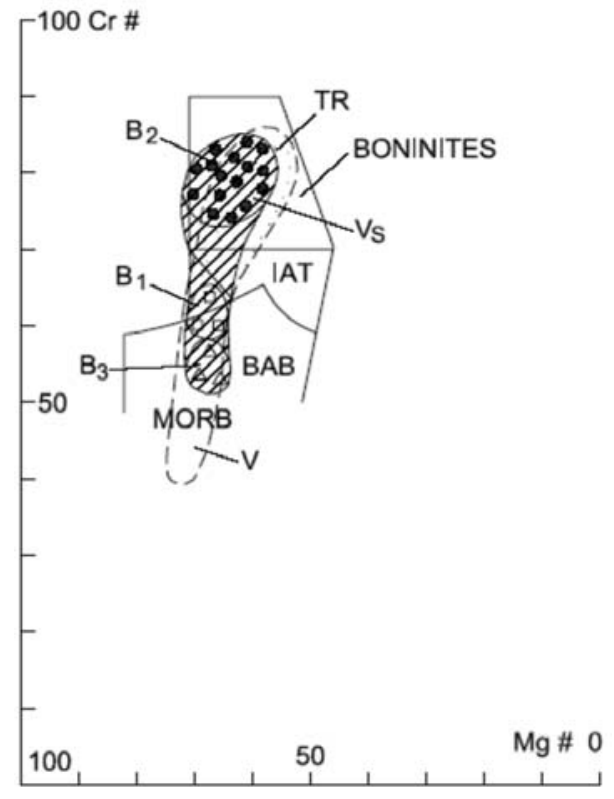

Fig. 5: Cr\# versus Mg\# for chromites of B-Bulqiza massif, Albania and of similarly, V- Vourinos and TR- Troodos with reference to boninitic lavas from Western Pacific, IAT and MORB environments (Data from Dick and Bullen, 1984; Economou et al., 1986; Panayiotou et al., 1986; Georgiou et al., 1990; Konstantopoulou et al., 1990; Gartzos et al., 1990. Chromite of Bulqiza massif related to: $\mathrm{B}_{1^{-}}$deep mantle $\mathrm{Cpx}$ - harzburgites; $\mathrm{B}_{2^{-}}$ ultramafic cumulates; $\mathrm{B}_{3}$ - mantle harzburgite-dunitic, dunitic-harzburgitic and super MOHO dunitic parts; VsSouthern Vourinos massif.

\subsubsection{The composition of olivine and the equilibrium temperature.}

The compositional change of olivine is also very interesting, from baren dunitic lenses towards the dunitic envelops of the ore bodies, interstitial and inclusions of olivine within chromitite, Fo varies in the range from 90 to 96.5 (Table 2). According to $\mathrm{xMg}$ and $\mathrm{xFe}$ variations in olivine and spinel, the temperatures, calculated on the $\mathrm{Ol}-\mathrm{Sp}$ termometer (by Lehmann, 1981) vary widly, from 650 to $750 \mathrm{C}^{0}$ for the chromitite, up to $800^{\circ} \mathrm{C}$ for accessoire chromites (Table 3 ).

The differences of Fm reflects the evolution of $\mathrm{Ol}$ - Sp equilibrium process depended from the grade of chromite concentration. So the chromitite $\mathrm{Ol}$ - Sp equilibrium has been more prolongated and was interopted in lower temperatures. On the contrary, for schiren and especially for accessorial chromites this equilibrium has been blocked early, in high temperatures. As suggested by Economou (1984) the systematic variation of olivine composition is propably a result of subsolidus reaction.

\section{Conclusions}

The Bulqiza ultramafite massif belongs to Eastern ophiolite belt of Albania. It is the most important chromite-bearing in Alpin Mediterranean belt.The rock composition of this massif mainly by mantle harzurgites and super -MOHO dunites , and by fosteritic olivine and enstatitic orthopyroxen, rock - forming minerals, is distinguished by high magnesian character. This is due to high partial melting of upper mantle and intensively mantle -crust interaction . In the consequence, a thick superMOHO dunitic sequence is formed. The ultramafic - mafic intrusive rocks are present also. The consequence of hight partial melting, the upper part of ultramafic pile is high consumptioned and impoverished by $\mathrm{CaO}$ and $\mathrm{Al}_{2} \mathrm{O}_{3}$ and enriched by $\mathrm{MgO}$ and $\mathrm{Cr}_{2} \mathrm{O}_{3}$. The chromite mineralization is situated at all ultramafic pile, but the most important chromite potential belongs to harzburgite -dunitic and partly to super -MOHO dunitic part , about from 300m down super- MOHO level, to 1200m. The predominant chromitite is of $\mathrm{Cr}$ - rich chromite high - grande ore, metallurgical - type. Among 
Table 2.

\begin{tabular}{|l|l|l|l|l|l|l|}
\hline \multicolumn{7}{|c|}{ Table 2 Chemical analyses of olivine } \\
\hline & \multicolumn{1}{|c|}{1} & \multicolumn{1}{c|}{2} & \multicolumn{1}{c|}{3} & \multicolumn{1}{c|}{4} & \multicolumn{1}{c|}{5} & \multicolumn{1}{c|}{6} \\
\hline $\mathrm{SiO}_{2}$ & 40.98 & 41.53 & 41.02 & 40.65 & 41.08 & 41.2 \\
\hline $\mathrm{FeO}$ & 7.85 & 7.24 & 4.06 & 5.08 & 2.99 & 2.78 \\
\hline $\mathrm{CaO}$ & 0.04 & 0.05 & 0 & 0 & 0.01 & 0.04 \\
\hline $\mathrm{Al}_{2} \mathrm{O}_{3}$ & 0.04 & 0.02 & 0 & 0.01 & 0 & 0 \\
\hline $\mathrm{MnO}$ & 0.33 & 0.02 & 0 & 0.04 & 0.06 & 0.01 \\
\hline $\mathrm{MgO}$ & 49.79 & 50.87 & 55.29 & 55.39 & 56.46 & 56.09 \\
\hline & & & & & & \\
\hline $\mathrm{Cr}_{2} \mathrm{O}_{3}$ & 0 & 0.06 & 0 & & 0.03 & 0.18 \\
\hline $\mathrm{NiO}$ & 0.5 & 0.33 & 0.67 & 0.4 & 0.62 & 0.67 \\
\hline $\mathrm{Total}$ & 99.55 & 100.1 & 100.66 & 101.94 & 101.25 & 100.97 \\
\hline & & & & & & \\
\hline $\mathrm{Si}$ & 1 & 1 & 0.972 & 0.97 & 0.97 & 0.974 \\
\hline $\mathrm{Fe}$ & 0.16 & 0.15 & 0.081 & 0.1 & 0.059 & 0.055 \\
\hline $\mathrm{Mn}$ & 0 & 0 & 0 & 0.01 & 0.01 & 0 \\
\hline $\mathrm{Mg}$ & 1.81 & 1.83 & 1.963 & 1.95 & 1986 & 1.977 \\
\hline $\mathrm{Cr}$ & & & & & 0.001 & 0.003 \\
\hline $\mathrm{Ni}$ & 0.01 & 0.01 & 0.012 & 0.007 & 0.012 & 0.013 \\
\hline $\mathrm{Total}$ & 2.98 & 2.99 & 3.025 & 3.028 & 3.029 & 3.023 \\
\hline $\mathrm{Fo}$ & 91.1 & 92.3 & 95.18 & 94.7 & 96.5 & 96.7 \\
\hline $\mathrm{Fa}$ & 8.9 & 7.7 & 4.82 & 5.3 & 3.5 & 3.3 \\
\hline
\end{tabular}

1-In harzburgite; 2-In dunite; 3 and 4 - interstitial in chromite; 5 and 6- inclusions within chromite.

Table 3.

\begin{tabular}{|c|c|c|c|c|c|c|c|c|c|c|c|c|c|}
\hline & Table 3. & \multicolumn{7}{|c|}{ The equilibrum temperatures after olivine - spinel couple } & & & & & \\
\hline & \multirow[b]{2}{*}{$\mathrm{Al}$} & \multicolumn{7}{|c|}{ Number of atoms in elementary cell of chromite and olivine } & & & & \multirow[b]{2}{*}{$\mathrm{Fm}$} & \multirow{2}{*}{$\begin{array}{l}\text { Temp C } \\
\text { Lehm. }\end{array}$} \\
\hline & & $\mathrm{Cr}$ & $\mathrm{Fe}^{3+}$ & $\mathrm{Fe}^{2+}$ & $\mathrm{Mg}$ & $\mathrm{FM}$ & $\mathrm{CAF}$ & Si & $\mathrm{Mg}$ & $\mathrm{Fe}^{2+}$ & Fo & & \\
\hline & & & & \multicolumn{2}{|c|}{ CHROMITE } & & & & & \multicolumn{2}{|c|}{ OLIVINE } & & \\
\hline 1 & 0.386 & 1.471 & 0.134 & 0.208 & 0.78 & 0.219 & 0.738 & 0.97 & 1.986 & 0.056 & 0.965 & 0.029 & 673 \\
\hline 2 & 0.31 & 1.6 & 0.085 & 0.362 & 0.627 & 0.373 & 0.802 & 0.969 & 1.951 & 0.1 & 0.947 & 0.049 & 795 \\
\hline 3 & 0.466 & 1.416 & 0.107 & 0.246 & 0.745 & 0.256 & 0.711 & 0.973 & 1.971 & 0.062 & 0.965 & 0.031 & 648 \\
\hline 4 & 0.331 & 1.548 & 0.112 & 0.28 & 0.707 & 0.292 & 0.777 & 0.971 & 1.966 & 0.078 & 0.957 & 0.038 & 750 \\
\hline 5 & 0.418 & 1.469 & 0.109 & 0.267 & 0.74 & 0.265 & 0.732 & 1.003 & 1.185 & 0.073 & & 0.037 & 704 \\
\hline 6 & 0.364 & 1.541 & 0.089 & 0.286 & 0.706 & 0.295 & 0.772 & 0.972 & 1.973 & 0.07 & & 0.034 & 693 \\
\hline 7 & 0.319 & 1.548 & 0.128 & 0.243 & 0.748 & 0.258 & 0.775 & 0.964 & 1.99 & 0.068 & 0.961 & 0.033 & 730 \\
\hline 8 & 0.375 & 1.53 & 0.091 & 0.301 & 0.689 & 0.31 & 0.766 & 0.969 & 1.963 & 0.081 & 0.952 & 0.04 & 799 \\
\hline 9 & 0.049 & 1.418 & 0.129 & 359 & 653 & 0.355 & 0.71 & 1.003 & 1.843 & 0.109 & & 0.056 & 794 \\
\hline 10 & 0.558 & 1.335 & 0.101 & 0.406 & 0.581 & 0.417 & 0.669 & 0.964 & 1.888 & 0.173 & 0.912 & 0.085 & 891 \\
\hline 11 & 0.341 & 1.611 & 0.048 & 0.595 & 0.411 & 0.591 & 0.805 & 0.96 & 1.834 & 0.207 & & 0.101 & 942 \\
\hline
\end{tabular}

1 to 8;Chromitites; 9; Chromitic dunites; 10 and 11; Harzburgites. $\mathrm{FM}=\mathrm{Fe}^{2} /\left(\mathrm{Fe}^{2+} \mathrm{Mg}\right)$ atom., $\mathrm{CAF}=\mathrm{Cr} /\left(\mathrm{Cr}+\mathrm{Al}+\mathrm{Fe}^{3+}\right)$ atom. 
them the other less important chromitite of Cr-rich metallurgical type also , but low - grande ores are related to super-MOHO dunites. The different restricted chromite ores, Al-rich, refractory type, are related to deep cpx -harzburgites and, in countrary at top of ultramafite - mafite sequences.The intensively partial melting of upper mantle is not fully sufficient argument to explain the high chromite concentration. As is suggested by Nicolas at al., (1991) the slow spreading, oxygen fugacity and the cool action of overlayered crust have played also their role for this concentration. The correlation between geological setting and the morphology, chromite -type, ore grande, chemical composition of chromite and textural features of chromitite, and ol - sp subsolidus reaction, are the arguments for the magmatic origin, complicated by later geodynamic processes.

\section{Acknowledgements.}

The author would like to express his appreciation to Zdenek Johan , Maryse and Daniel Ohnenstetter for their precious suggestions on chromite mineralization and for assistence with the electron microprobe analyses at BRGM - France. I wish to express my thank to Maria Economou - Eliopoulos, Alexander Panayitou and G. Migiros for their data on investigations about Greece and Cyprus chromite mineralization.

\section{References}

Alliu, I., Beccaluva, L., Çina, A., Coltorti, M., et al ., 1994. The Skanderbeg and Bulqiza mafic- ultaramafic ophiolitic complexes and their relationship with chromititic ore deposits Working group meeting of IGCP project No 256- fild trip B).Ofioliti, 19(1),. 27 - 55.

Auge, T. and Johan Z., 1988. Comparative study of chromite deposits from Troodos, Vurinous, North. Oman and New Caledonia ophiolites .Mineral Depozits, ed by Boisson as and P.Omenetto, Springer -Verlag Berlin. 267-288.

Burgath ,K. P., Krauss, U., Mohr,M., 2002 . Chromium ores and plantinum - group. element. occurrences in Europe and Turkey: Inventory, evolution and possibilities Chron. Rech . No. hors serie,, 55-77..

Çina, A., 1986. Some physical proprieties of the chromitite chromespinels of the ophiolitic ultrabasiic massif of Bulqiza, Albania.Ofioliti, 11, Nr.1, 51.

Çina, A., Caslli, H. and Goci, L., 1986. Chromites in the ophiolites of Albanides. In:"Chromites".UNESCO'S -197project, Metallogeny of ophiolites. Theophrastus Pub.S.A Athens, 107-126.

Dick, H.J.Band, Bullen,T.,1984 .Chromian spinel as a petrogenic indicator in abisal and alpine-type peridotites and spatially associated lavas. Contribution to Mineralogy and Petrology, v.86, 54-76.

Dietrich, V.,oberhansli,R.and Marcolli ,I. 1987. A new occurrence of boninite from the ophiolitic mélange in the Pindus-subpelagonian zone.Ofioliti ,12,83-90.

Economou, M., Dimou, E., Economou, G., Vacandios, I., Grivas E., Rassios, A. and Dabitzias, S., 1986.Chromite deposits of Greece. In : Chromites UNESCO'S -197project, Metallogeny of ophiolites. Theophrastus Pub. S.A Athens, 129-159.

Economou, M. 1984. On the chemical composition of the chromite ores from the Chalkidi peninsula,. Greece ofiolitu, 9(2), 123-134.

Gartzos, E., Migiros, G.and Parcharidis, I. 1990. Chromites from ultramafic rocks northen Evia (Greece) and their geotectonic significance. Scheiz Mineral. Petrogr. Mitt, 70, 301-307.

Georgiu, E and Xenophontos, C. 1990. Chromite occurrances and associated plutonic rocks in the Akapnou Forest. In :Ophiolites,oceanic crustal analogues.Proc of the Symp”Troodos1987”. Nicosia Cyprus. 585-592.

Karaj. N., 1992. Repartition des platinoides, des chromites et sulfures dans le massif de Bulqiza,. Alba- 
nie. Incidence sur les proccesus metallogeniques dans les ophiolites. These, Univ d'Orleans, pp.400.

Kodra, A., Gjata, K. and Bakalli, F., 1995. The Mirdita oceanic basin from rifting to the closure. In:: Workshop on Albanian ophiolites and related mineralizations. Documents du BRGM. 244. Editions BRGM, France 9-26.

Konstantopoulou, G. and Economou, M-Eliolopoulos 1990. Geochemistry of the Vourinos chromite ores, Greece. In: Ophiolites, oceanic crustal analogues. Proc. of the Symp”Troodos 1987”. Nicosia, Cyprus. 605-613.

Nicolas, A., Bondier, F. and Meshi, A., 1999. A slow spreading accretionin the ophiolite of. Mirdita (Albania). Jurnal of Geophysical Reseacher. 104, nr.87, 15155-15167.

Ohnenstetter, M., Karaj, N., Neziraj, A., Johan, Z., Çina, A. 1991: Le potentiel platinifere des ophiolites: Mineralizations en elements du groupe du platine (EGP) dans les massifs de Tropoja et Bulqiza, Albanie. C.R. Acad. Scie. Fr., v .313, ser. II.201-208.

Panayiotou, A., Michaelides, A.E. and Georgiou, E., 1986. The chromite deposits of the Troodos. Ophiolite complex, Cyprus. Chromites UNESCO'S IGCP.197 Project Metallogeny of ophiolites. Theophrastus Pub. S.A Athens. 161-198

Shallo, M., Çina, A. and Turku, I., 1995. Outline of metallogeny of the Albanian MOR and SSZ- type ophiolites. In: Workshop on Albanian ophiolites and related mineralization. Documents du BRGM 244. Editions BRGM, France, 27-46. 